This item was submitted to Loughborough's Research Repository by the author.

Items in Figshare are protected by copyright, with all rights reserved, unless otherwise indicated.

\title{
A facile and mild synthesis of enamides using a gold-catalyzed nucleophilic addition to allenamides
}

PLEASE CITE THE PUBLISHED VERSION

http://dx.doi.org/10.1021/ol1001494

PUBLISHER

(C) American Chemical Society

VERSION

AM (Accepted Manuscript)

LICENCE

CC BY-NC-ND 4.0

REPOSITORY RECORD

Kimber, Marc C.. 2019. "A Facile and Mild Synthesis of Enamides Using a Gold-catalyzed Nucleophilic Addition to Allenamides”. figshare. https://hdl.handle.net/2134/13946. 
This item was submitted to Loughborough's Institutional Repository (https://dspace.lboro.ac.uk/) by the author and is made available under the following Creative Commons Licence conditions.

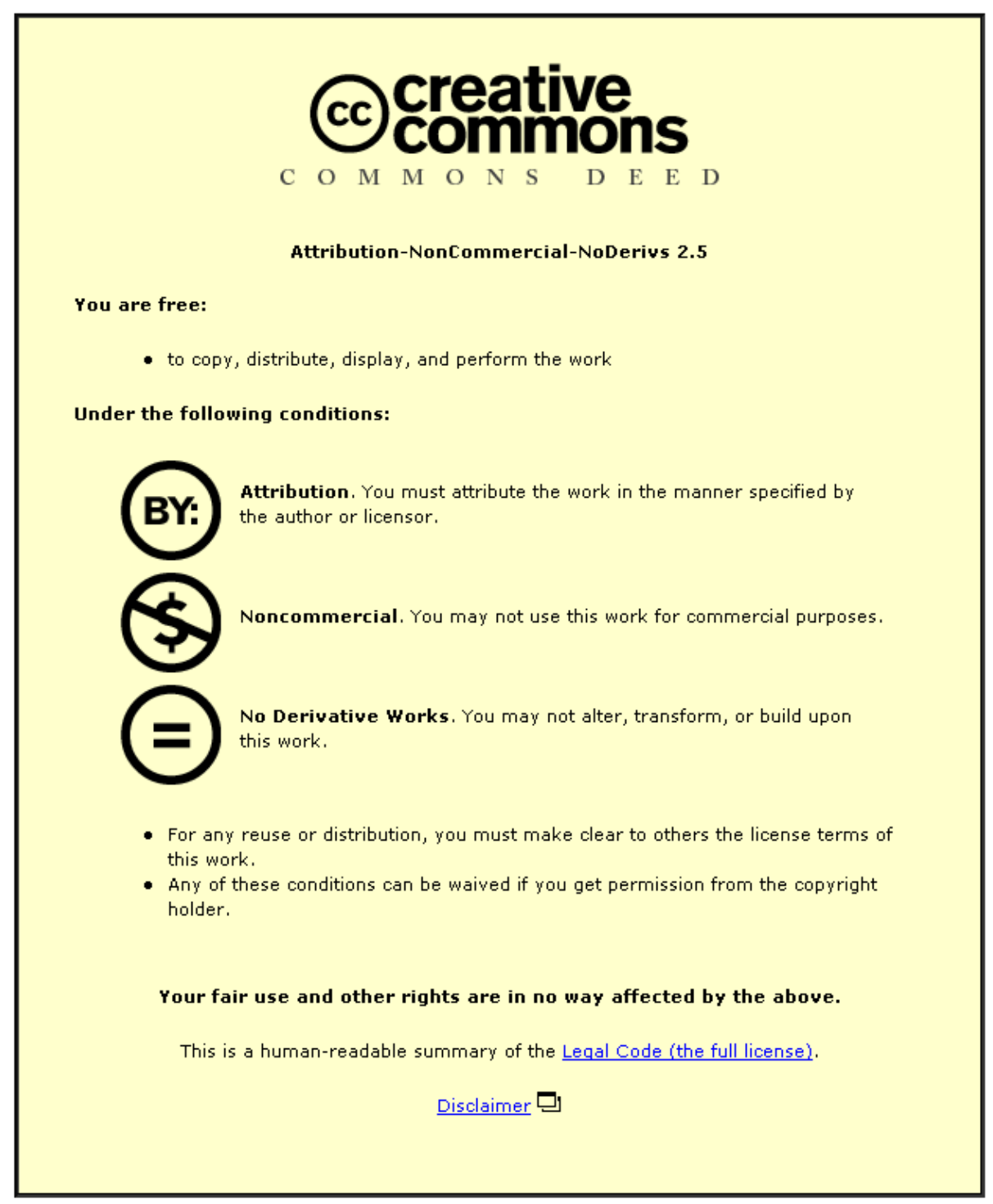

For the full text of this licence, please go to: http://creativecommons.org/licenses/by-nc-nd/2.5/ 


\title{
A Facile and Mild Synthesis of Enamides using a Gold Catalyzed Nucleophilic Addition to Allenamides
}

\author{
Marc C. Kimber \\ Department of Chemistry, Loughborough University, Leicestershire LE11 $3 T U$ \\ M.C.Kimber@lboro.ac.uk
}

Received Date (will be automatically inserted after manuscript is accepted)

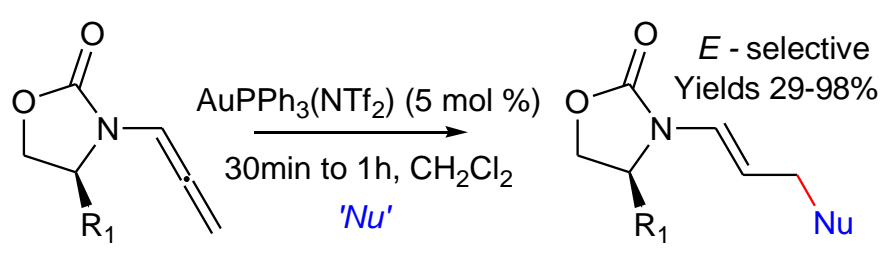

$\mathrm{Nu}=$ electron rich aromatic/heteroaromatic

A mild and facile synthesis of enamides has been developed based on nucleophilic addition of electron rich aromatic and heteroaromatics to an allenamide unit catalysed by a gold salt. Yields for the transformation were between $29-98 \%$.

Enamides have become an increasingly valuable and hence topical functional group within the synthetic community. ${ }^{1}$ They are contained in a number of natural product frameworks such as the chondriamides, salicylihalamides and within cyclic peptides. They have also been used as asymmetric synthetic precursors within the context of heterocyclic and amine synthesis. ${ }^{2}$ The unique reactivity that enamides display has led to the development of a number of general and $E / Z$ selective syntheses. To date the synthesis of enamides has often been centred around condensation of an amide equivalent with the corresponding carbonyl funtionality. ${ }^{3}$ However

\footnotetext{
${ }^{1}$ For a review see Carbery, D. R. Org. Biomol. Chem. 2008, 6, 3455.

2 Davyt, D.; Entz, W.; Fernandez, R.; Mariezcurrena, R.; Mombru, A. W.; Saldana, J.; Laura Domınguez; Coll, J.; Manta, E. J. Nat. Prod. 1998, 61, 1560. Yet, L. Chem. Rev. 2003, 103, 4283. Tan, N.-H.; Zhou, J. Chem. Rev. 2006, 106, 840. Gallier, F.; Hussain, H.; Martel, A.; Kirschning, A.; Dujardin, G. Org. Lett. 2009, 11, 3060. Xiao, D.; Zhang, Z.; Zhang, X. Org. Lett. 1999, 1, 1679. Sibi, M. P.; Asano, Y. J. Am. Chem. Soc. 2001, 123, 9708

${ }^{3}$ Rappoport, Z. in The Chemistry of Enamines; Wiley: Chichester, 1994. Zezza, C. A.; Smith, M. B. Synth. Commun. 1987, 17, 1532.
}

more elaborate and novel methods such as organocuprate addition to isocyanates, ${ }^{4}$ acylation of in situ prepared imines $^{5}$ and an $N$-acylation/Peterson elimination process ${ }^{6}$ have also been developed. Complementing these methods a number of transition metal catalyzed approaches based on $\mathrm{C}-\mathrm{N}$ bond forming reactions $(\mathrm{Pd}, \mathrm{Cu}),{ }^{7}$ isomerizations of allyl amides $(\mathrm{Fe}, \mathrm{Rh}, \mathrm{Ru}){ }^{8}$ addition of amides to alkynes $(\mathrm{Ru})$, organometallic additions to ynamides $(\mathrm{Rh}){ }^{9}$

\footnotetext{
${ }_{5}^{4}$ Snider, B. B.; Song, F. Org. Lett. 2000, 2, 407.

${ }_{5}$ Robert K. Boeckman, J.; Goldstein, S. W.; Walters, M. A. J. Am. Chem. Soc. 1988, 110, 8250.

${ }^{6}$ Fürstner, A.; Brehm, C.; Cancho-Grande, Y. Org. Lett. 2001, 3 , 3955.

Klapars, A.; Campos, K. R.; Chen, C..; Volante, R. P. Org. Lett. 2005, 7, 1185. Brice, J. L.; Meerdink, J. E.; Stahl, S. S. Org. Lett. 2004, 6, 1845. Wallace, D. J.; Klauber, D. J.; Chen, C.; Volante, R. P. Org. Lett. 2003, 5, 4749. Cesati III R. R; Dwyer, G.; Jones, R. C.; Hayes, M. P.; Yalamanchili, P.; Casebier, D. S. Org. Lett. 2007, 9, 5617. Bolshan, Y.; Batey, R. A. Angew. Chem. Int. Ed. 2008, 57, 2109. Chemler, S. R.; Fuller, P. H. Chem. Soc. Rev. 2007, 36, 1153.

${ }^{8}$ Stille, J. K.; Becker, Y. J. Org. Chem. 1980, 45, 2139

${ }^{9}$ Gourdet, B.; Rudkin, M. E.; Watts, C. A.; Lam, H. W. J. Org. Chem. 2009, 74, 7849 .
} 
Heck couplings $(\mathrm{Pd}),{ }^{10}$ co-oligomerization of $\mathrm{N}$-vinyl amides $(\mathrm{Ru})^{11}$ and oxidative conjugate additions $(\mathrm{Pd})^{12}$ have also been reported (Scheme 1).

Scheme 1. Transition metal strategies in enamide synthesis

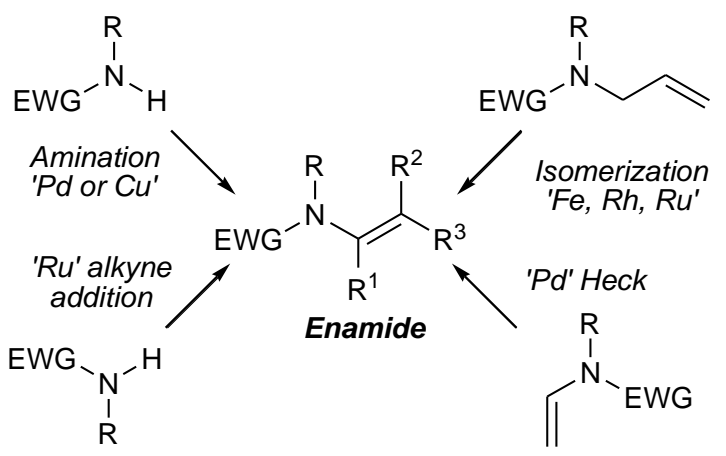

In the synthesis of enamides the relationship between enamides and allenamides, both of which contain the desired sp2 carbon attached directly to the amide, has yet to be fully exploited. Allenamides represent a fascinating and versatile functional group whose chemical utility has been exploited by a number of groups. ${ }^{13}$ The chemistry in which allenamides have participated in include radical cyclizations,${ }^{14}$ tandem epoxidation/cycloadditions, ${ }^{15}$ Pauson Khand cyclizations, ${ }^{16}[4+2]^{17}$ and $[4+3]^{18}$ cycloadditions, acid catalyzed cyclizations /rearrangments, ${ }^{19}$ palladium mediated transformations, ${ }^{20}$ cyclopropanations, ${ }^{21}$ base catalyzed $\mathrm{CO}_{2}$ capture ${ }^{22}$ and finally gold mediated transformations. ${ }^{23}$

\footnotetext{
${ }^{10}$ Vallin, K. S. A.; Zhang, Q.; Larhed, M.; Curran, D. P.; Hallberg, A. J. Org. Chem. 2003, 68, 6639. Harrison, P.; Meek, G. Tetrahedron Lett. 2004, 45, 9277.

11 Tsujita, H.; Ura, Y.; Matsuki, S.; Wada, K.; Mitsudo, T.-a.; Kondo, T. Angew. Chem. Int. Ed. 2007, 46, 5160.

${ }^{12}$ Lee, J. M.; Ahn, D.-S.; Jung, D. Y.; Lee, J.; Youngkyu Do; Kim, S. K.; Chang, S. J. Am. Chem. Soc. 2006, 128, 12954.

${ }^{13}$ Wei, L.-L.; Xiong, H.; Hsung, R. P. Acc. Chem. Res. 2003, 36.

14 Shen, L.; Hsung, R. P. Org. Lett. 2005, 7, 775.

15 Huang, J.; Hsung, R. P. J. Am. Chem. Soc. 2005, 127. Rameshkumar, C.; Hsung, R. P. Angew. Chem. Int. Ed. 2004, 43, 615.

16 Anorbe, L.; Poblador, A.; Dominguez, G.; Perez-Castells, J. Tetrahedron Lett. 2004, 45. González-Gómez, A.; Añorbe, L.; Poblador, A.; Domínguez, G.; Pérez-Castells, J. Eur. J. Org. Chem. 2008, 1370.

${ }^{17}$ Berry, C. R.; Hsung, R. P. Tetrahedron 2004, 60. Song, Z.; Hsung, R. P.; Lu, T.; Lohse, A. G. J. Org. Chem. 2007, 72, 9722. Lohse, A. G.; Hsung, R. P. Org. Lett., 2009, 11, 3430.

18 Xiong, H.; Huang, J.; Ghosh, S. K.; Hsung, R. P. J. Am. Chem. Soc. 2003, 125 .

${ }^{19}$ Hayashi, R.; Hsung, R. P.; Feltenberger, J. B.; Lohse, A. G. Org. Lett. 2009, 11, 2125. Berry, C. R.; Hsung, R. P.; Antoline, J. E.; Petersen, M. E.; Challeppan, R.; Nielson, J. A. J. Org. Chem. 2005, 70, 4038.

${ }^{20}$ Beccalli, E. M.; Broggini, G.; Clerici, F.; Galli, S.; Kammerer, C.; Rigamonti, M.; Sottocornola, S. Org. Lett. 2009, 11, 1563. Fuwa, H.; Sasaki, M. Org. Biomol. Chem. 2007, 5, 2214. Ma, S.; Gu, Z.; Yu, Z. J. Org. Chem. 2005, 70, 6291.

${ }^{21}$ Lu, T.; Hayashi, R.; Hsung, R. P.; DeKorver, K. A.; Lohse, A. G.; Song, Z.; Tang, Y. Org. Biomol. Chem. 2009, 7, 3331.

${ }^{22}$ Chen, G.; Fu, C.; Ma, S. Org. Lett. 2009, 11, 2900.

23 (a) Hyland, C. J. T.; Hegedus, L. S. J. Org. Chem. 2006, 71, 8658. (b) Manzo, A. M.; Perboni, A. D.; Broggini, G.; Rigamonti, M. Tetrahedron Lett. 2009, 50, 4696.
}

The use of gold salts for the activation of allenamides is an attractive concept as it would negate the use of acidic conditions for allenamide activation ${ }^{24}$ and would therefore be more functional group tolerant. ${ }^{25}$ It is in this class of reactions, catalyzed by gold salts, in which we thought we could make a contribution within the context of direct intermolecular arylations (Scheme 2).

Scheme 2. Intermolecular gold addition to allenmamides

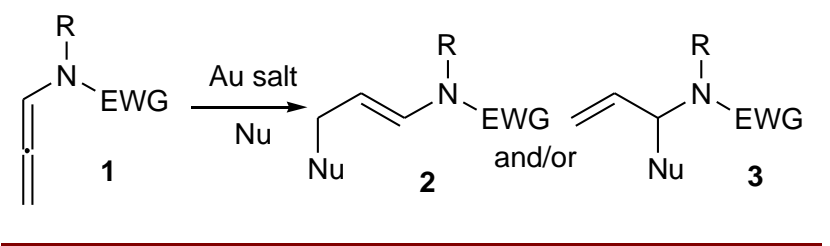

To date there have only been two reports of gold catalyzed cyclization of allenamides and in both cases the attacking nucleophile has been intramolecular and a heteroatom, forming either 2,5-disubstituted dihydrofurans $^{23 \mathrm{a}}$ or vinylimidazolidinones ${ }^{23 \mathrm{~b}}$ via a 5-exotet mechanism in each case. However, for the intermolecular gold catalysed addition of nucleophiles to activated allenamides there have been no reports to our knowledge. $^{26}$

In the intermolecular addition there is an issue of regioselectivity (Scheme 2). Addition of the nucleophile to the terminal carbon of the gold activated allenamide $\mathbf{1}$ would potentially deliver enamide 2, alternatively addition to the carbon adjacent to the nitrogen would deliver the allylic amine 3 . In this study we wished to explore this regioselectivity issue via the addition of carbon nucleophiles to an activated allenamide. To activate the allenamide we have chosen to utilize gold salts and the attacking nucleophiles which we selected for the study would be electron rich aromatics and heteroaromatics which we expect to add to the activated allenamides via a Friedel-Crafts type mechanism.

Our test substrate for this study would be the allenamide 5a which was convieniently synthesized in 2 steps using the method of Wei et al. (Scheme 3). ${ }^{27}$ With $\mathbf{5 a}$ in hand, a trial reaction with 1-methylindole, 6a, in the presence of $5 \mathrm{~mol} \%$ of in situ prepared $\mathrm{AuPPh}_{3} \mathrm{OTf}$ in $\mathrm{CH}_{2} \mathrm{Cl}_{2}$ was performed (Scheme 4).

\footnotetext{
${ }^{24}$ Navarro-Vazquez, A.; Rodriguez, D.; Martınez-Esperon, M. F.; A. Garcia; Saa, C.; Dominguez, D. Tetrahedron Lett. 2007, 48, 2741. Kinderman, S. S.; Wekking, M. M. T.; Maarseveen, J. H.; Schoemaker, H. E.; Hiemstra, H.; Rutjes, F. P. J. T. J. Org. Chem. 2005, 70, 5519.

${ }^{25}$ Hashmi, A. S. K.; Rudolph, M. Chem. Soc. Rev. 2008, 37, 1766. Hashmi, A. S. K. Chem. Rev. 2007, 107, 3180. Arcadi, A. Chem. Rev. 2008, 108,3266 .

${ }^{26}$ One reviewer kindly pointed out that the intermolecular addition of $\mathrm{HCl}$ to a pyrazol-allene giving the pyrazol-allylchloride has been reported, Baikalova, L. V.; Zyryanova, I. A.; Tarasova, O. A.; Chipanina, N. N.; Shmidt, E. Yu.; Kashik, T. V.; Afonin, A. V.; Sinegovskaya, L. M.; Vashchenko, A. V.; Trofimov, B. A. Russ. J. Gen. Chem. 2003, 73, 1634.

${ }^{27}$ Wei, L.-L.; Mulder, J. A.; Xiong, H.; Zificsak, C. A.; Douglas, C. J.; Hsung, R. P. Tetrahedron 2001, 57, 459.
} 
Scheme 3. Synthesis of allenamides $\mathbf{5 a , b}$<smiles>[R7]C1([R7])COC(=O)N1</smiles>

a) $\mathrm{NaH}, \mathrm{THF}$<smiles>[R7]C1([R7])COC(=O)N1C=C=C</smiles>

(b) $\mathrm{THF},{ }^{\mathrm{B}} \mathrm{BuOK}$

$$
\begin{aligned}
& \text { 5a: } R^{1}=R^{2}=H[64 \%] \\
& \text { 5b: } R^{1}=B n, R^{2}=H[72 \%]
\end{aligned}
$$

4a: $R^{1}=R^{2}=H$

To our delight the starting material was consumed within $30 \mathrm{~min}$ and a new product was detected by tlc. This was subsequently isolated and shown to be the indole enamide $7 \mathbf{a}$ by a combination of ${ }^{1} \mathrm{H},{ }^{13} \mathrm{C}$ NMR and IR spectroscopy (Scheme 4). The spectroscopic data for $7 \mathbf{a}$ show, inter alia, a doublet at $6.80(J=14.4 \mathrm{~Hz})$, double triplets at $5.01(J=14.4$ and 6.8) and doublet at $3.51(J=$ $6.8 \mathrm{~Hz}$ ) as well as an absorbance at $1671 \mathrm{~cm}^{-1}$ in the IR spectrum, all indicative of an $E$-enamide. This result confirmed that addition of the indole nucleophile occurs at the terminus of the activated allenamide as opposed to the carbon adjacent to the nitrogen.

Scheme 4.

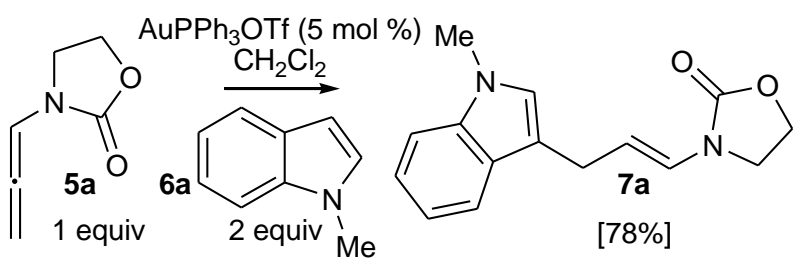

While the yield for this transformation was adequate, we next set out to optimize our reaction conditions, the results of which are summarized in Table 1.

Table 1. Intermolecular arylation of allenamide $\mathbf{5 a}$ with $N$-methylindole $\mathbf{6} \mathbf{a}^{a}$

\begin{tabular}{clccc}
\hline entry & \multicolumn{1}{c}{ catalyst } & $\begin{array}{c}\text { equivalents } \\
\text { of 6a }\end{array}$ & $\begin{array}{c}\text { time }^{b} \\
(\mathrm{~h})\end{array}$ & $\begin{array}{c}\text { conversion }^{c} \\
{[\% \text { Yield] }}\end{array}$ \\
\hline 1 & $\mathrm{PPh}_{3}$ AuOTf & 2.00 & 0.5 & $100[82 \%]$ \\
2 & $\mathrm{PPh}_{3}$ AuOTf & 1.50 & 0.5 & 100 \\
3 & $\mathrm{PPh}_{3}$ AuOTf & 1.05 & 0.5 & 100 \\
$4^{d}$ & $\mathrm{AgOTf}$ & 1.05 & 16 & 0 \\
$5^{e}$ & $\mathrm{TFA}$ & 1.05 & 2.0 & 42 \\
6 & $\mathrm{PPh}_{3} \mathrm{Au}\left(\mathrm{NTf}_{2}\right)$ & 1.05 & 0.5 & $100[83 \%]$ \\
$7^{f}$ & $\mathrm{PPh}_{3} \mathrm{Au}\left(\mathrm{NTf}_{2}\right)$ & 1.05 & 1.0 & 95
\end{tabular}

${ }^{(a)}$ Reactions run with $5.0 \mathrm{~mol} \%$ of catalyst in $\mathrm{CH}_{2} \mathrm{Cl}_{2}$ at room temperature unless otherwise stated. ${ }^{(b)}$ Determined by disapperance of $5 \mathbf{a}$ by TLC analysis unless otherwise stated. ${ }^{(c)}$ Conversion was determined by ${ }^{1} \mathrm{H}$ NMR, isolated yield in brackets. ${ }^{(d)}$ No consumption of starting material was seen after $16 \mathrm{~h} .{ }^{(e)} 1$ equivalent of acid relative to 5a. ${ }^{(f)} 1.0 \mathrm{~mol} \%$ of catalyst
Variation of the number of equivalents of $\mathbf{6 a}$ from 2.0 to 1.05 had no effect on conversion to the desired product indicating that the reaction could be essentially carried out with equimolar amounts of the two reactants (entries 1,2 and 3 , respectively). Conducting the reaction in only the presence of AgOTf had no effect on the reaction with starting material being recovered (entry 4). TFA did promote the reaction, as expected, ${ }^{28}$ however the conversion was low compared to the gold catalyzed examples possibily due to product degradation, and significantly the rate of reaction was lower. Altering the gold source counter ion from OTf to $\left(\mathrm{NTf}_{2}\right)$ had no effect on the reaction (entry 6), also lowering the amount of gold catalyst from $5 \mathrm{~mol} \%$ to $1 \mathrm{~mol} \%$ had little effect on conversion but did result in increased reaction times (entry 7).

Scheme 5. Enamides synthesized from $\mathbf{5 a}$

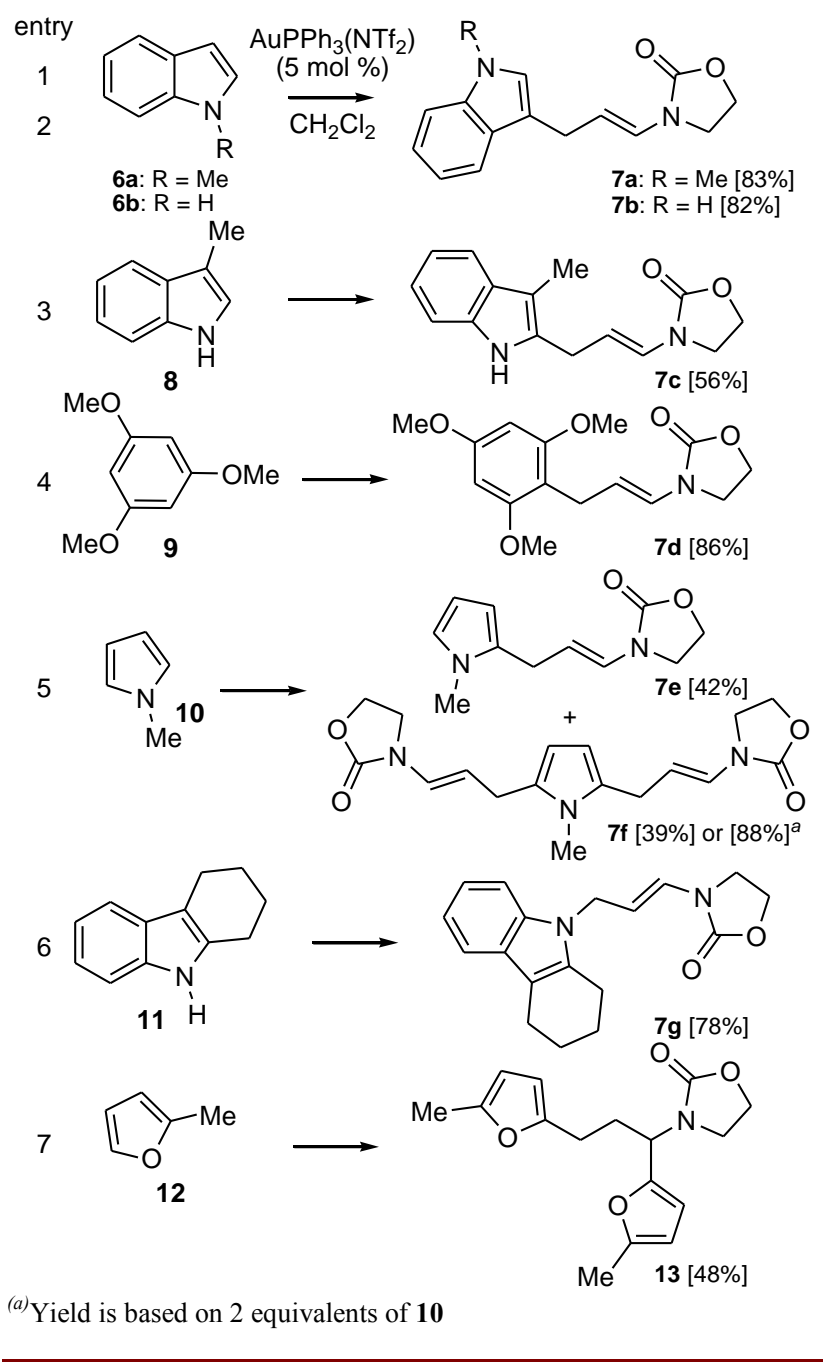

\footnotetext{
${ }^{28}$ Navarro-Vazquez, A.; Rodriguez, D.; Martınez-Esperon, M. F.; A. Garcıa; Saa, C.; Domınguez, D. Tetrahedron Lett. 2007, 48, 2741.
} 
With optimised conditions for the arylation determined the scope of this transformation was then explored (Scheme 5). $N$-Methylindole 6a and indole $\mathbf{6 b}$ reacted with allenamide $\mathbf{5 a}$ to give the enamides $7 \mathbf{a}$ and $\mathbf{7 b}$ in good yields (entries 1 and 2). 3-Methylindole 8 gave the 2 -substituted enamide $\mathbf{7 c}$ in modest yield with the remaining mass balance being accounted for by the $\mathrm{N}$ substituted enamide (entry 3 ). ${ }^{29}$ This is where reaction has occurred through the indole $\mathrm{NH}$ and suggests that intermolecular enamide synthesis is attainable using heteroatoms. While anisole failed to add to allenamide $\mathbf{5 a}$, the more electron rich 1,3,5-trimethoxy benzene 9 added in good yield to give 7d (entry 4). $N$-Methyl pyrrole 10 gave a mixture of the mono- and disubstituted enamides $7 \mathbf{e}$ and $7 \mathbf{f}$ in modest yields (entry 5). Increasing the amount of $\mathbf{1 0}$ relative to allenamide 5a to 2 equivalents gave exclusively the disubstituted enamide $7 \mathbf{f}$ in an excellent yield of $88 \%$. Based on the result from using indole 8, tetrahydrocarbozole $\mathbf{1 1}$ gave exclusively the $\mathrm{N}$ substituited enamide $\mathbf{7 g}$ in a yield of $78 \%$ (entry 6). Finally, addition of 2-methyl furan $\mathbf{1 2}$ gave the amide $\mathbf{1 3}$ in a modest yield, presumably due to a second addition of 12 to the intially formed enamide (entry 7). ${ }^{30}$

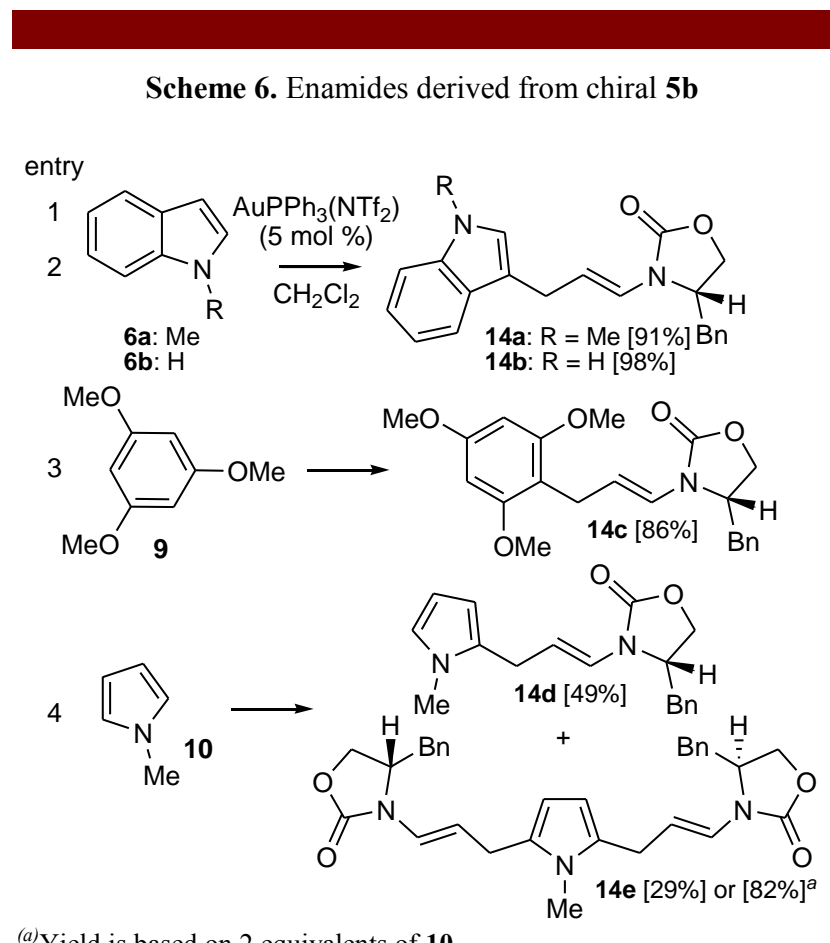

(a) Yield is based on 2 equivalents of $\mathbf{1 0}$

Chiral allenamide $5 \mathrm{~b}$ was coupled to $\mathbf{6 a}, \mathbf{6 b}, \mathbf{9}$ and $\mathbf{1 0}$ under the same catalytic gold conditions (Scheme 6). The yields mirrored that of the achiral allenamide 5a and significantly all enamides 14a-e were delivered with no racemisation of the stereogenic centre (entries 1 to 4 ).

\footnotetext{
${ }^{29}$ See structure 22 supporting information for physical data

${ }^{30}$ The ${ }^{1} \mathrm{H}$ NMR spectra does indicate a small amount of the enamide is formed during the reaction, see the supporting information.
}

A plausible mechanism for this transformation is presented in Scheme 7. Initial $\mathrm{Au}$ complexation to 5a could be via pathway A or B, however pathway A could be energetically unfavourable due to the formation of a primary carbocation 17 . However, both pathways A and B deliver the key intermediate conjugated acyliminium 19 that can undergo 1,4-addition by a nucleophile giving $\mathbf{2 0}$. This then subsequently undergoes protodemetallation giving the enamide 21.

Scheme 7. Plausible mechanism

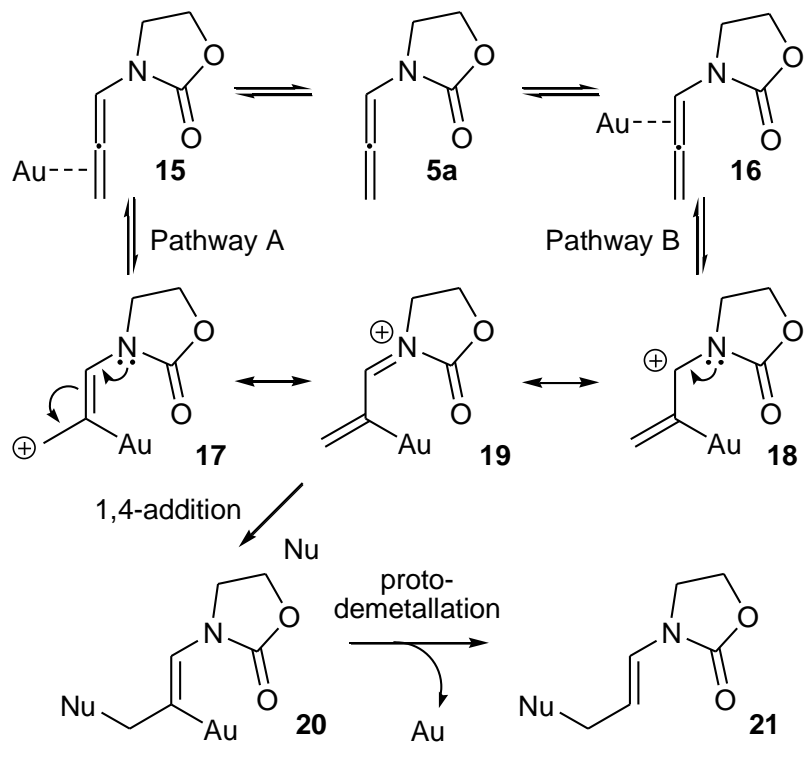

In summary we have demonstrated for the first time that the intermolecular gold catalyzed addition of electron rich aromatics and heteroaromatics to activated allenamides is regioselective and high yielding. This method delivers the desired enamides under very mild conditions, with no exclusion of air during the reaction and in very short reaction times as compared to many of the $\mathrm{Pd}, \mathrm{Ru}, \mathrm{Rh}$ and $\mathrm{Cu}$ coupling methods. The use of this transformation in further intermolecular transformations, multi component reactions and its use in natural product synthesis will be reported on in due course.

Acknowledgment The author thanks Loughborough University for financial support and Dr Mark Edgar (Department of Chemistry, Loughborough University) for NMR analysis.

Supporting Information Available. Experimental procedures, NMR spectra and characterization for all new materials. This material is available free of charge via the Internet at http://pubs.acs.org. 
